Article

\title{
Sustainable Policy Measures Based on Implementation of Digital Technologies in Corrections: Exploratory Study from Slovakia and Beyond
}

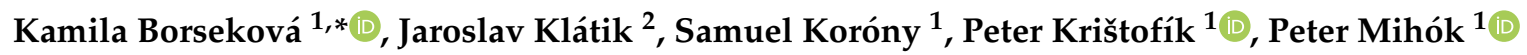 \\ and Martin Orviský ${ }^{2}$ \\ 1 Faculty of Economics, Matej Bel University, Tajovského 10, 97401 Banská Bystrica, Slovakia; \\ samuel.korony@umb.sk (S.K.); peter.kristofik@umb.sk (P.K.); peter.mihok@umb.sk (P.M.) \\ 2 Faculty of Law, Matej Bel University, 97401 Banská Bystrica, Slovakia; jaroslav.klatik@umb.sk (J.K.); \\ martin.orvisky@umb.sk (M.O.) \\ * Correspondence: kamila.borsekova@umb.sk
}

Received: 1 October 2020; Accepted: 14 October 2020; Published: 19 October 2020

check for updates

\begin{abstract}
Across the world, millions of people are incarcerated every year, while hundreds of thousands of them are released back into their home communities. Despite several alternatives within the criminal justice system, incarceration is still considered as the most natural method of correction. This can lead to different types of unsustainable pathways within a society. Despite the growing importance and increasing use of digital technologies, there are relatively few scientific studies related to the implementation of digital technologies in corrections. Therefore, the present paper aims to assess the sustainable policy measures based on the implementation of digital technologies in corrections, namely electronic monitoring (EM). The originality of our paper is supported by unique primary data gathered during the first national survey on the assessment of sustainability measures of EM in Slovakia. Our research reveals that EM implementation contributes to individual and institutional resilience in a socio-economic context; the requirements for a conditional release of serious offenders with mandatory EM seem to have created sustainable conditions for the use of this form of the EM "back door" scheme. EM programs are aimed at suppressing crime through increased accountability and monitoring, which leads to their sustainability. Maintaining social and family ties, reducing risk of imprisonment and undesirable new ties, and keeping working habits are the main sustainable policy measures of EM that support better social inclusion of offenders. Assessment of the sustainable policy measures based on the implementation of digital technologies in corrections, namely electronic monitoring (EM) uncovered in the present paper, creates space for further research and policy implications. Data protection, automated data processing and artificial intelligence in the implementation of digital technologies in corrections are important topics that deserve much more attention in research.
\end{abstract}

Keywords: digital technologies; sustainable policy measure; electronic monitoring (EM); cost effectiveness; legal context; socio-economic context

\section{Introduction}

Across the world, millions of people are incarcerated in public and private facilities. Every year, hundreds of thousands of them are released back into their home communities. In the United States of America, almost half of them are rearrested within a year. These issues have been excluded from mainstream sustainability narratives, despite their serious implications for sustainability [1]. 
Incarceration is a traumatic experience not only for the individuals sentenced to imprisonment, but also for their families and communities, as well as for the society [1-3]. Despite several alternatives within the criminal justice system, incarceration is still considered as the most natural method of correction. This can lead to different types of unsustainable pathways within a society. First, the growing number of prisoners leads to serious prison overcrowding, resulting in unsustainable prison conditions, given the relevant human rights. Second, incarceration as a correction is commonly overused, for it can be counterproductive for vulnerable groups, and for those only responsible for minor offences. Third, incarceration is often the most expensive of all correction methods [4].

One of the more intriguing experiments in criminal justice reform is the replacement of incarceration by mandatory electronic monitoring (EM) based on using different types of digital technologies [5-7]. EM is mainly used to detain, restrict or monitor. Its subjects may be forbidden from entering restricted areas, or contacting specified individuals, and the monitoring may be continuous [8].

EM currently entails the use of radiofrequency/landline telephone technology to know remotely but in the real time whether tagged offenders abide by the conditions to of a court-imposed curfew (usually made to their own home, overnight). Variants of this technology can monitor and measure alcohol and drug intake of curfewed offenders. Voice verification permits the checking of an offender's presence at multiple rather than single locations. Satellite tracking-using Global Positioning System (GPS) satellites and the mobile phone system - monitors movement and facilitates the specification of exclusion zones rather than mere presence at particular locations [9] (p. 67). It was designed so that offenders need not remain in prison, whether in pre-trial detention, or serving their sentence. It was intended to be a financially cheaper and/or socially more beneficial alternative to imprisonment. Thus, the EM schemes must be cost effective and sustainable [10]. In the era of austerity measures and calls for more efficient provisioning of public services, EM presents a sustainable alternative to incarceration for many countries.

The stated aims of EM are usually to reduce the use of custody without increasing the risk to the public; to avoid the "contamination factor" in imprisonment, when first offenders mix with more experienced offenders and learn the "tricks of the trade"; to avoid the stigma of prison and the dislocation of family ties [11]. Generally, EM has been used for offenders committing a range of crime types, mostly less serious crimes [12,13]. Although the initial motive for EM was humane and a cheaper alternative to detention, the motives as well as the use of electronic monitoring gradually changed and expanded. Many other programs have been implemented and EM has received several additional functions $[7,8,14]$. Therefore, an important policy debate has been taking place about EM use "as a stand-alone punishment (commonplace in England and Wales, but less so elsewhere in Europe) versus its use as a component in intensive supervision and treatment programmes, although even in regard to the latter there have been arguments as to whether it is included simply as a punitive element in the package, or whether it serves to support other, more rehabilitative components." [15] (p. 2). "EM might be used at all stages of the criminal justice process: as a pre-trial, as a sentence, as an early release from prison and also after completion of a prison sentence, potentially providing the only universal mechanism for reducing prison populations. Furthermore, EM is a flexible tool, which may be used in many ways in the criminal or civil justice context. For example, it can be used as a standalone measure or alongside other requirements or conditions. Also, EM regimes are infinitely flexible so monitoring periods may be tailored to the intensity required and changed during the lifetime of orders" [11] (p. 8).

EM implementation varies across countries. Some countries use EM as an autonomous standalone sentence (e.g., Belgium, Slovakia, Great Britain) or as an alternative to imprisonment in the case of short-term sentences (for example in France and Norway). The longest sentence under EM applied so far was in Belgium, approx. 3.5 years [16]. A different approach than in Belgium (and England and Wales) has been taken by the authorities in the Netherlands, perceiving the key value of EM "in terms of rehabilitation, provided that EM would be combined with an intensive support program and 'meaningful activities' such as schooling or work" [17] (p. 1). Besides, EM has been implemented in the Netherlands 
only for a very short unconditional prison sentences in the length of up to 90 days, for offenders without a "security risk" [17].

Similarly, EM is considered a proper alternative to incarceration for short prison sentences in France or Norway, or in the form of a house arrest in Italy, Lithuania and Poland. In France, "while under EM, offenders are compelled to respect strict home curfews for long hours, with permission to leave only for work or other rehabilitative activities" [18] (p. 30). In contrast to all the above-mentioned European countries, the legislation and practice on the federal level in Germany does not allow application of EM as an alternative to imprisonment. Germany uses EM only as a decision of the European Court of Human Rights no. 19359/04, which authorizes 24-h police surveillance of the most dangerous perpetrators after returning from prison [19].

Despite the growing importance and increasing use of digital technologies, there are relatively few scientific studies related to the implementation of digital technologies in corrections. Most of the contributions are not based on empirical research but only describe the application of EM or focus on EM in terms of its effectiveness as a method of punishment (for more information, see [9,20-24].

Solid, in-depth empirical surveys have only been conducted in a small number of European countries and are very country-specific (e.g., [25] in Belgium and [26-28] in England and Wales). Similar surveys were conducted outside Europe, in the USA (e.g., [6,7,13]), New Zealand [29,30], Israel [31,32] and Argentina [33]). The above mentioned studies provide a rather narrow basis for this relatively large issue, while we did not find any study related to assessment of sustainable policy measures based on implementation of digital technologies in corrections. The general motivation of this paper is to bring the new insight to this topic. Therefore, the present paper aims to cover this gap through conducting in-depth empirical research in Slovakia, supplemented by selected international experience and data.

EM was introduced in Slovakia by Act no. 78/2015 Coll. on the control of the execution of selected (legal) decisions by means of technical instruments [34]. The parts of this Act covering the EM pilot project came into force on 1 July 2015, and the remaining parts, covering the permanent EM program, came into force on 1 January 2016. The Act allows EM applications in civil procedural law, for certain preliminary measures, and in all stages of the criminal justice process. These included EM during pre-trial; EM as an alternative to imprisonment-also known as the "front door scheme"; EM after early release from prison-also known as the "back door scheme"; and after release from prison, having served the full sentence-also known as the "post-sentence scheme".

The specific motivation of the paper is to assess the possible sustainable policy measures based on the implementation of digital technologies in corrections, namely electronic monitoring (EM), and assess the impact of EM implementation on individual or institutional sustainability in the legal and socio-economic contexts, while considering the situation in Slovakia supported by international experience.

The remainder of the paper is organized as follows: The second section focuses on materials and methods. The third section, divided into two main sub-sections, presents the robust research results focused on electronic monitoring as a sustainability measure in the socio-economic and legal contexts. The last section concludes and discusses the most important research results and outlines steps for policy implications and further research.

\section{Materials and Methods}

This paper focuses on the assessment of EM as a sustainability measure. In the first stage, we focus on an exploratory study of EM as a sustainability measure based on the literature (introduction in Section 3.1). In the second stage, an exploratory study of cost effectiveness of EM based on data analysis is employed (Section 3.1.1). We offer evidence from 8 countries of similar population size as Slovakia. Subsequently, we focus on an analysis and comparison of opinions of judges, and of probation and mediation officers, reached in the original national survey, on possible sustainability 
measures of EM, as defined in the literature. In Section 3.2, we perform an in-depth analysis of EM as a sustainability measure in the legal context, with particular orientation towards back-door schemes.

A broad comparative and exploratory study of these phenomena would need a wide array of consistent information. There is indeed an avalanche of information on electronic monitoring implementation across the world, but most of this information is available in anecdotal form, e.g., in news (media or public debates). There is not much systematics in the definition and collection of data, aside from quantitative data.

The main goal of the paper was-as mentioned before-to assess the possible sustainable policy measures based on the implementation of digital technologies in corrections, namely electronic monitoring (EM).

The main sources of secondary data on electronic monitoring in European countries are studies published by [35-37]. According to our knowledge, the above mentioned references are the only official sources of electronic monitoring data in Europe that provide the relevant financial data needed to compare the financial costs of incarceration and EM. We supplemented the analysis of the results of the studies with data from the Council of Europe published in the Annual Report on Criminal Proceedings: Data on Prisoners from 2018, and data provided in scientific papers on electronic monitoring in Europe.

Besides, the article presents analyses of (1) the content of the original law that introduced EM into the Slovak criminal justice system, and its first amendment; (2) the content of the official Ministry of Justice (MoJ) documents that accompanied the government proposals for the law, and its first amendment; (3) MoJ data on the application of those laws; and (4) original empirical data collected in a national survey of opinions of judges, probation and mediation officers. We undertook the national survey from May to September 2019, administering it to 144 anonymous respondents, who were representative in terms of gender, regional distribution, age and level of experience, of both (a) judges and (b) probation and mediation officers. Some analyses of data, for example comparisons of answers between a group of probation and mediation officers and a group of judges, were made by the IBM SPSS (version 25) statistical system. This paper uses only those parts of the survey that relate to assessing the sustainability and implementation of the EM legislation.

The key approach used in the preparation of this article was an in-depth analysis of the above noted materials. To enhance the clarity of our findings, where possible, we present the results in graphic or tabular forms. When preparing figures, we used MS Excel files publicly disclosed by the MoJ whenever possible, attempting to eliminate our own additions to them.

\section{Results}

This section is divided into two main sub-sections. The first subsection is oriented towards EM as a sustainability measure in the socio-economic context. Sustainability is determined by a range of criteria as defined in the literature, including cost and the outcomes flowing from the interventions. The Section 3.1. includes cost effectiveness of EM and evaluation of the views of judges, and also of the probation and mediation officers, on the sustainability of the Slovak EM program. The main contribution of this section depicts the table in the Section 3.1.2 as it illustrates our selection of relevant results of the national survey of judges and probation and mediation officers which, in our opinion, characterise the key aspects of sustainability of the Slovak EM program.

The second subsection is oriented towards EM as a sustainability measure in the legal context. The Section 3.2 aims to evaluate whether the Laws that allow "back door" EM in the Slovak criminal justice system are sustainable, and to describe their current operation. It therefore compares the content of the original EM Laws (valid in 2016-2018) to that of the amended Laws (in force from 1 January 2019), and analyses the results of the "back door scheme" of the first Slovak EM program under these very different laws. 


\subsection{Electronic Monitoring as a Sustainability Measure in the Socio-Economic Context}

EM policy assumes as its primary "problem" the risk of reoffending in the context of a high prison population, supposedly resulting from previous governments' policy failures. A further problem to be "fixed" is public confidence, namely the public perception of safety when offenders are released back into the community [38] (pp. 5-6). There is evidence from the literature (inter alia $[4,27,39-41]$ ) that EM brings socio-economic benefits and contributes to individual and institutional sustainability in this matter. The economic context of EM as a sustainability measure is perceived through cost reduction related to significantly lower direct and indirect costs than those of incarceration. In this matter, EM reduces the use of custody without increasing risk to the public. It decreases the excess costs to society of the personnel, resources and facilities required to arrest, detain, try, convict, and supervise offenders, beyond the cost of incarcerating convicted offenders for the terms of their sentences. The social context of EM as a sustainability measure is in offering suitable ways of punishment for vulnerable groups of persons (pregnant woman, youthful, terminally ill, etc.) or for persons causing minor crimes. This kind of punishment eliminates the negative influence of other prisoners on offenders and supports the normal inclusion of offenders in the family and other social networks. It also eliminates the intergenerational transfer of crime, due to the fact that children whose parents are career criminals are likely to be at high risk of becoming criminals themselves. Moreover, the offenders can remain employed and continue any treatment initiated in the community [42]. The above mentioned aspects support the inclusion of offenders into society with the help of using modern digital technologies.

\subsubsection{Cost Effectiveness of EM}

There are several studies assessing the cost effectiveness of EM [20,43-48]. The study [43] showed that a 90-day curfew period with a tagged offender is around GBP 5300 cheaper than a custodial sentence of the same length. EM, including home arrest and home detention, could be very effective in terms of costs and in aborting the criminal careers of individuals who would otherwise settle into a pattern of habitual offending. EM produces positive externalities that influence cost efficiency and sustainability of the whole jurisdiction system [49]. EM decreases the costs to society of the rehabilitation counselling, and of treatment services that are required when convicts exit prison; the excess cost to society of the personnel, resources and facilities required to arrest, detain, try, convict, and supervise offenders, beyond the cost of incarcerating convicted offenders for the terms of their sentences; and costs related to the intergenerational transfer of crime, due to the fact that children whose parents are career criminals are likely to be at high risk of becoming criminals themselves [48].

Besides the above mentioned costs, it needs to be taken into consideration that electronically monitored persons are allowed to work in many European jurisdictions (for example in France, Portugal, Slovakia, Sweden, UK, etc.). This means that those persons pay taxes, health and social insurance and have the usual consumption of goods and services that favour the local economy. In several countries (for example, Slovakia), electronically monitored persons are obliged to contribute to costs of their EM from their own resources [49], which refers to the individual social responsibility of the person being electronically monitored. All these savings and cost related externalities have to be considered by evaluation of EM cost-efficiency and thus financial sustainability [39].

For estimation of the cost effectiveness of EM, we used data already processed by [35]. The Table 1 compares public spending on incarceration and electronic monitoring in 2012 and 2017 in selected countries. The choice of countries is based on data availability and similar country size in terms of population to Slovakia. 
Table 1. Comparison of individual costs for incarceration versus costs for EM (Electronic Monitoring) in selected countries.

\begin{tabular}{|c|c|c|c|c|c|c|c|}
\hline & Austria & $\begin{array}{l}\text { Czech } \\
\text { Republic }\end{array}$ & Denmark & Ireland & Latvia & Norway & Sweden \\
\hline $\begin{array}{l}\text { Average daily costs } \\
\text { for incarceration } \\
(2012)\end{array}$ & $107 €$ & $36.40 €$ & $186 €$ & $179 €$ & $12.52 €$ & $283 €$ & $317 €$ \\
\hline $\begin{array}{l}\text { Average daily cost } \\
\text { for EM (2012) }\end{array}$ & $22 €$ & $25 €$ & $56 €$ & $6.45 €$ & $4 €$ & $100 €$ & $3.50 €$ \\
\hline $\begin{array}{c}\text { Cost for } \\
\text { incarceration/ } \\
\text { Cost for EM (2012) }\end{array}$ & 4.86 & 1.46 & 3.32 & 27.75 & 3.13 & 2.83 & 90.57 \\
\hline $\begin{array}{l}\text { Average daily costs } \\
\text { for incarceration } \\
(2017)\end{array}$ & $129 €$ & $46.50 €$ & $202 €$ & $188 €$ & $23.30 €$ & $283.50 €$ & $380 €$ \\
\hline $\begin{array}{l}\text { Change in daily } \\
\text { costs for } \\
\text { incarceration } \\
2017 / 2012\end{array}$ & 1.206 & 1.277 & 1.086 & 1.05 & 1.861 & 1.002 & 1.199 \\
\hline $\begin{array}{l}\text { Estimated costs of } \\
\text { EM with the same } \\
\text { change in costs as in } \\
\text { the case of } \\
\text { incarceration when } \\
\text { abstracting from } \\
\text { other influences }\end{array}$ & $26.52 €$ & $31.94 €$ & $60.82 €$ & $6.77 €$ & $7.44 €$ & $100.18 €$ & $4.20 €$ \\
\hline
\end{tabular}

The data in Table 1 confirm the findings on lower average daily costs of electronic monitoring compared to incarceration, and thus the cost effectiveness of EM as an alternative way of punishment. Due to the later implementation of EM in Slovakia, this country is not involved in the table. According to $[36,37,50]$, the average daily cost of prisoners in penal institutions in Slovakia was EUR 39.39 in 2014 and EUR 43.70 in 2017. The total budget for the prison administration in 2014 was EUR 150,579,357 and in 2017 it increased to EUR 163,898,082 (corresponding to $8.85 \%$ growth). This is the period when Slovakia started to implement electronic monitoring. According to the estimation of the MoJ of the Slovak Republic in 2015, the annual costs of electronic monitoring should amount to approximately EUR 6700 per one electronically monitored person per year, which means that the average daily costs would reach EUR 18.36. However, this evaluation assumed the use of the full capacity of the Slovak system, approximately 1500 monitored persons simultaneously. As we do not have any information concerning estimated actual costs of implementing electronic monitoring in Slovakia, we cannot provide an estimation of the costs per one electronically monitored person per year in Slovakia [51]. A lack of relevant data from Slovakia, but also many other countries, seems to be the most serious bottleneck for international comparative research in this area. In order to reflect this unfavorable situation, we conducted the first national empirical survey on EM in Slovakia.

\subsubsection{Results of the National Survey on EM Sustainability Measures}

This section records the opinions of judges, and of probation and mediation officers, on possible sustainability measures of EM, as defined in the literature [20,31-39,50-56], see Table 2. 
Table 2. Opinion patterns on sustainability measures of EM.

\begin{tabular}{|c|c|c|c|c|c|}
\hline \multirow[b]{2}{*}{$\begin{array}{c}\text { Sustainability Measures } \\
\text { of EM }\end{array}$} & \multicolumn{2}{|c|}{$\begin{array}{c}\text { Probation and Mediation } \\
\text { Officer }\end{array}$} & \multicolumn{2}{|c|}{ Judge } & \multirow{2}{*}{$\begin{array}{c}\text { M-W } \\
\text { Test }\end{array}$} \\
\hline & Mean & Median & Mean & Median & \\
\hline $\begin{array}{l}\text { EM reduces the cost of } \\
\text { serving the sentence }\end{array}$ & 4.24 & 4.00 & 4.07 & 4.00 & 0.113 \\
\hline $\begin{array}{l}\text { EM increases the safety } \\
\text { of citizens }\end{array}$ & 3.40 & 4.00 & 2.93 & 2.50 & 0.007 \\
\hline $\begin{array}{l}\text { EM improves the social } \\
\text { inclusion of prisoners }\end{array}$ & 4.02 & 4.00 & 3.60 & 4.00 & 0.008 \\
\hline EM reduces recidivism & 3.16 & 3.00 & 2.55 & 2.00 & 0.001 \\
\hline $\begin{array}{l}\text { EM increases confidence in } \\
\text { alternative sanctions }\end{array}$ & 3.77 & 4.00 & 3.48 & 4.00 & 0.136 \\
\hline $\begin{array}{c}\text { EM improves family } \\
\text { protection (in terms of social } \\
\text { ties, income, etc.) }\end{array}$ & 4.50 & 5.00 & 4.02 & 4.00 & 0.000 \\
\hline $\begin{array}{l}\text { EM mitigates the economic } \\
\text { consequences of } \\
\text { the custodial sentence for } \\
\text { the convict and their family }\end{array}$ & 4.43 & 5.00 & 4.05 & 4.00 & 0.007 \\
\hline $\begin{array}{l}\text { EM mitigates the social } \\
\text { consequences of } \\
\text { the custodial sentence for } \\
\text { the convict and their family }\end{array}$ & 4.34 & 4.00 & 4.02 & 4.00 & 0.013 \\
\hline $\begin{array}{l}\text { EM strengthens family } \\
\text { protection against } \\
\text { family violence }\end{array}$ & 3.40 & 4.00 & 2.86 & 3.00 & 0.008 \\
\hline $\begin{array}{l}\text { EM limits hooliganism } \\
\text { at events }\end{array}$ & 3.71 & 4.00 & 3.32 & 4.00 & 0.037 \\
\hline $\begin{array}{l}\text { EM increases the protection } \\
\text { of sensitive sites }\end{array}$ & 3.74 & 4.00 & 3.38 & 4.00 & 0.039 \\
\hline $\begin{array}{l}\text { EM is an effective } \\
\text { instrument for the control of } \\
\text { the offender }\end{array}$ & 4.29 & 4.00 & 3.89 & 4.00 & 0.001 \\
\hline
\end{tabular}

Notes: Mean—arithmetic mean, $p-p$ value of a two-sided Mann-Whitney (M-W) test.

A national Survey was conducted under the research project noted below in the Funding section, with the cooperation of the MoJ during the summer of 2019. The survey was distributed to all judges and probation and mediation officers in Slovakia related to all types of judicatures authorised to impose EM. It was distributed in an electronic form, using the email databases of the MoJ. We have received 144 responses, from which $56.9 \%$ was represented by judges and $43.1 \%$ was represented by probation and mediation officers, equally distributed by the age, gender and regions in Slovakia, and thus the sample is representative. The rationale behind involving both judges and probation and mediation officers in the national survey is as follows. Judges can both propose and rule on proposals to apply EM. Probation and mediation officers apply the EM conditions, including installation, operation, and maintenance, problem solving and dismantling of the equipment. These officers are the most relevant stakeholders on the operational side of the EM control regime, and have the most reliable and realistic views on whether its effects signal that it is a sustainable policy.

The Table 2 summarizes the list of possible EM sustainability measures, and the opinions of judges, probation and mediation officers. Answers are coded on an ordinal five-level Likert scale as follows: 
1-Strongly disagree, 2-Disagree, 3-Neither agree nor disagree, 4-Agree and 5-Strongly agree. Therefore, the range of values is from one to five. For the distribution differences of answers between groups we used the nonparametric Mann-Whitney test.

The results of the national survey show that judges and "probation and mediation officers" have similar but not identical views on the EM sustainability measures. Both groups identified the most important, i.e., effective EM sustainability measures, as the reduction in costs of serving the sentence, the improvement in family protection, and mitigation of the economic and social consequences of the custodial sentence. The results of the Mann-Whitney test show that probation and mediation officers show substantial agreement on the EM sustainability measures, except for reduction in costs, and increasing confidence in alternative sanctions.

For all sustainability measures, probation and mediation officers had a more positive view of the effects of EM than did judges, if we compare mean answers. If we use median scores, then, across all the measures, officers have a higher or the same view as judges of the success of EM interventions.

\subsection{Electronic Monitoring as a Sustainability Measure in the Legal Context}

When considering the legal perception of EM as a sustainability measure in Slovakia, this article focuses solely on the "back door scheme" of the first Slovak EM program. So it concerns the use of $\mathrm{EM}$ as of a mandatory instrument for checking compliance with the conditions of the two different legal forms of early release from prison. These are (1) conversion of the remainder of a sentence into electronically monitored house arrests, and (2) conditional release with mandatory EM. The reason why we focus on the "back door" scheme is because the first amendment to the EM Laws was almost exclusively concerned with the "back door scheme". It was prepared by the Ministry of Justice (MoJ) in August 2018, and approved by the Parliament in October 2018 as Act no. 321/2018 Coll. [57], in force from the 1st of January 2019. Apart from amending the Slovak EM Act no. 78/2015, it also amended the Criminal Procedure Code, the Penal Code, the Act on probation and mediation officers, and two other Slovak Acts (note: approval of the second amendment to the EM Laws, which concerned mostly the "front door" scheme, was delayed until mid-2019, and only came into force from August 2019).

In this section, we deal with two key amendments to the EM Laws that concerned the "back door" scheme. First, a significant change of the eligibility conditions for converting the remaining periods of prison sentences into EM house arrests for minor offenders. Second, the introduction of a new option for conditional prisoner releases with a mandatory EM, eligible only for those offenders whose crimes (Slovak criminal offences are either minor offences, or crimes. Minor offences are those committed by negligence or, if intentional, carry a maximum custodial penalty of not more than five years. A special part of the Criminal Code deals with crimes carrying sentences of more than five years. Those carrying a minimum custodial penalty of more than ten years are viewed as particularly serious.) had led to their first prison sentence(s). Section 3.2.1 presents our analysis of the original EM legislation, in force from 2016 to 2018. Section 3.2.2 covers our analysis of the amended EM legislation, in force since 1 January 2019. Section 3.2.3 provides a comparative analysis of the original and the amended EM legislation with respect to their eligibility criteria for converting prison sentence remainders into EM house arrest. Section 3.2.4 summarises the results of implementation of both the original and the amended EM legislation for the so-called "back-door" scheme. This compares the number of prisoners subjected to EM after converting their remaining prison sentences, with those subjected to mandatory EM after conditional release from prison.

\subsubsection{Settings for the EM “Back-Door" Scheme under the Original Laws (2016-2018)}

Under the original EM Law, in force from 2016 to 2018, there was no provision for a conditional release with mandatory EM for those sentenced to imprisonment for crimes. Minor offenders sentenced to imprisonment could, however, request a conditional release after serving half of the sentence. In contrast, prisoners serving sentences for crimes could request a conditional release after serving two thirds of their sentence. Finally, those serving prison sentences for serious crimes could request a 
conditional release from prison after serving three quarters of their sentence. I.e., the more serious the category of offence, the longer the relative wait for permission to request conditional release (without EM).

The original EM Law had introduced a new legal instrument, eligible only for prisoners serving sentences for minor offences, i.e., for minor offenders. From January 2016, provided they had served at least one third of their sentence, they could request to convert the remainder of their prison sentences, up to a maximum of two years, into house arrest with a mandatory EM. Alternatively, as noted above, provided they had served at least half of the sentence, they could request a conditional release without EM. For the prisoners serving short prison sentences, the typical trade-off was: serve an extra sixth of your sentence in prison, in return for no subsequent electronic monitoring during the remainder of the sentence (in case of a successful approval of a request for conditional release).

Figure 1 illustrates, on the vertical axis, how many months later (positive numbers), or sooner (negative numbers), those imprisoned for minor offences could submit requests for the conversion of the remainder of their sentence into EM house arrest, compared to how long they would have to wait to submit a request for a conditional release, based on the length of their sentence. The results were produced and publicly disclosed by the MoJ [58] in the documentation accompanying the first EM Law amendment. However, Figure 1 presents the same MoJ data in a different visual configuration from source [58]. The reason why the values 35 (months) and 36 (months) have been added to the MoJ data relate to the first EM Law amendment, and are explained in Section 3.2 below.

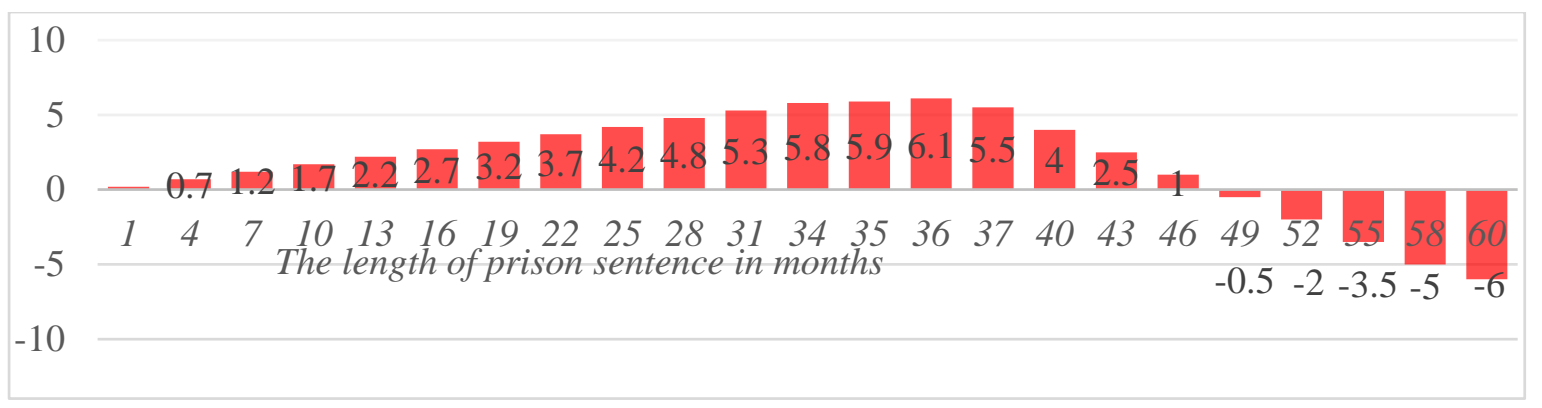

Figure 1. The vertical axis shows how many months later (positive numbers), or earlier (negative numbers), prisoners could submit requests for a conversion of the remainder of their sentence into EM house arrest, compared to the period of sentence served before being eligible to submit a request for conditional release, and how this varies with the length of the sentence. Operational 2016-2018 [58].

Figure 1 illustrates that the apparently more appealing option of leaving prison on a conditional release without EM, became available to eligible prisoners at most at 6.1 months later than the less appealing option of converting sentence remainders into EM house arrest (in the case of prison sentences of 36 months, i.e., 3 years). The latter status is less appealing because it would require an offender to wear an electronic bracelet, and also to remain at home when requested by the court. An important fact, which can be seen on the right hand side of Figure 1, is that the apparently more appealing option to leave prison on conditional release without EM came even earlier when the sentence was for more than 4 years.

Figure 1 suggests that the MoJ drafted the original EM Law so that its house arrest conversion provisions would be most beneficial for such minor offenders whose prison sentences were typically about three years long. Common minor offences with such penalties, under various sections of the Criminal Code, include Theft, Embezzlement, Payment Offences, and Fraud (For more information, see Chapter four of the Criminal code-offences against (the right of) property.), and also Unlawful Manufacturing and Use of Payment Cards, Electronic Money or Other Payment Means under Section 219 abs. 2 of the Criminal Code. 
3.2.2. Settings for the EM "Back Door" Scheme under the Amended Laws (Since 2019)

The two most important changes introduced by the first EM Law amendment were first, its changes to the conversion of remainders of prison sentences into EM house arrests, and second, the new regulations for conditional releases with a mandatory EM. The first changes, involving a "back-door" use of EM, raised the limit on the length of EM (during remainder of a sentence) from two to three years. However, this amendment only changed the conditions for sentences of over three years. That is why the MoJ added the two additional values of 35 months and 36 months to the figures it prepared and published in 2018 [58] (See: Reasoning statement, pp. 8-9). The figures provided a visual presentation of the fact that the first EM Law amendment would have no impact on prison sentences of this length, but only on longer ones.

Figure 2 suggests that the MoJ most probably drafted the original EM Law with the aim or expectation that EM imprisonment remainder conversions would be most beneficial to perpetrators of minor offences with prison sentences in the range 42-60 months. Such offences might be, for example, credit fraud, legalising the proceeds of crime, or usury. They could, however, also include unlawful Manufacturing and Enjoyment of Payment Cards, Electronic Money or Other Payment Cards under Section 219 abs. 1 of the Criminal Code (i.e., the same offence as already included amongst the frequent minor offences, for which conversion of prison sentence remainders into EM house arrest was eligible under the original legislation). This is an example of an eligible crime that was appropriate for the "back-door" EM scheme under both the original and amended EM legislation, because lengths of prison sentences for this crime can vary between one and eight years [39].

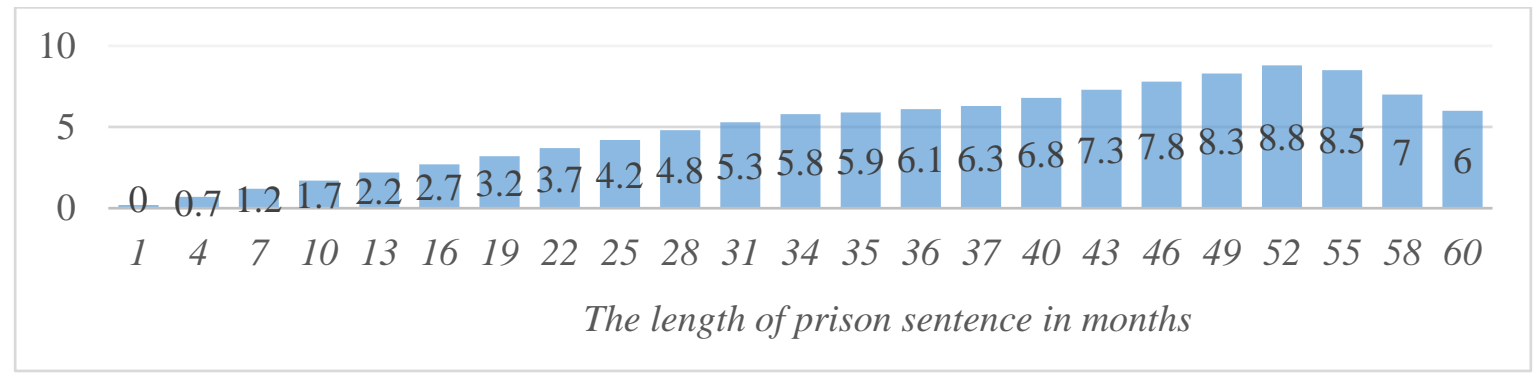

Figure 2. This figure shows how many months later (positive numbers) or earlier (negative numbers) prisoners could submit requests to convert the remainder of their sentences into EM house arrest, compared to the conditions for submitting a request for conditional release. Operational since 2019 [58].

3.2.3. Comparisons of the Original and Amended Conditions for Converting Remaining Prison Sentences into EM Monitored House Arrests

Figure 3 shows our own calculations, using MoJ data, of the impact of the two different MoJ regulations for converting remaining prison sentences into EM house arrests (red bars and blue bars) in relation to regulations for conditional release from prison without EM. The original sentences are shown on the horizontal axis. The minimum periods of imprisonment before access to a conversion of imprisonment into EM house arrest (under both the original and amended Laws) or access to conditional release scheme are shown on the vertical axis. The red bars show these minimum periods for converting remaining sentences to EM under the original 2016-2018 legislation. The blue bars show these minimum periods under the amended legislation, since 2019. The green bars show the minimum periods of imprisonment before eligibility for conditional release. 


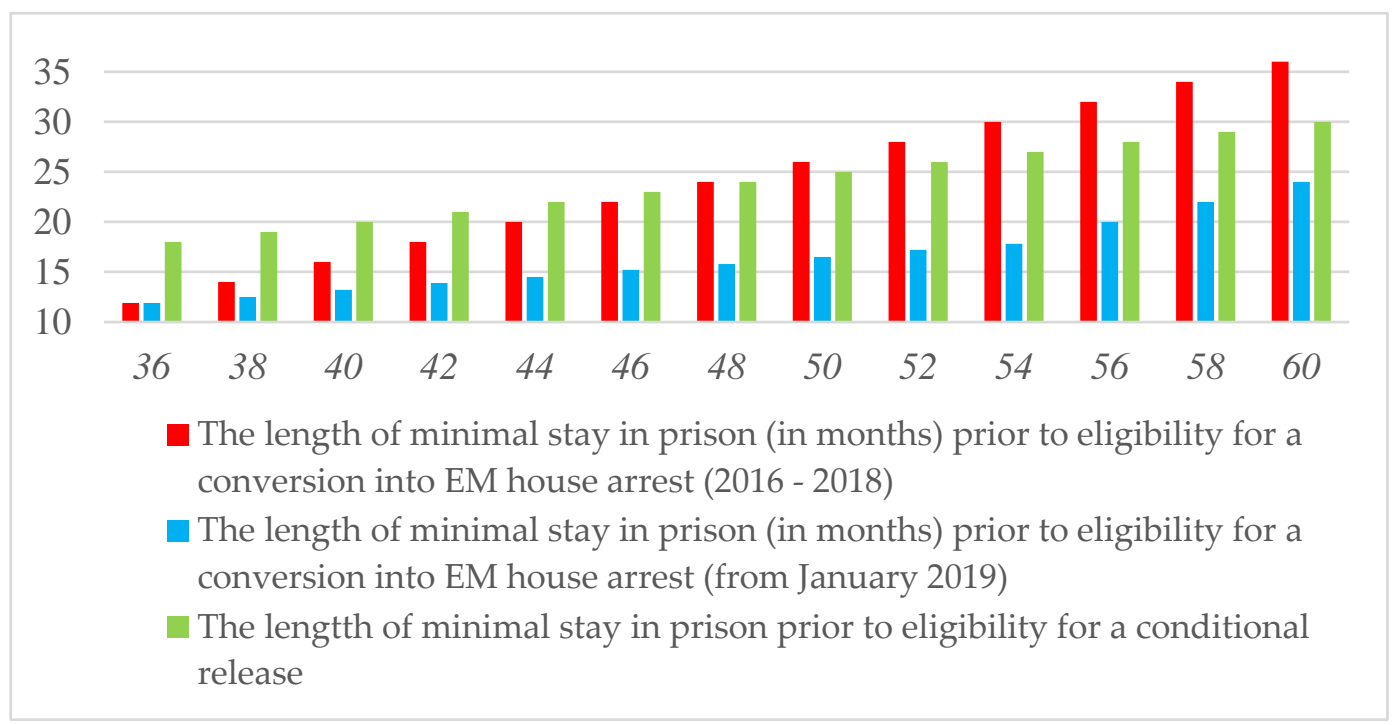

Figure 3. Compares the mandatory minimum prison stays before eligibility to submit a request to convert the rest of the sentence into EM house arrest, in 2016-2018 (in red), and since 2019 (in blue), to the minimum mandatory prison stays before eligibility to request a conditional release without EM (in green). Both axes are in months [58].

In contrast to Figures 1 and 2, which compared differences between converting imprisonment into EM house arrest and into conditional release, Figure 3 shows the minimum mandatory prison periods that needed to be served before the prisoner could apply for the original, respectively amended early release programme(s) considered in this section. Comparing the red bars to the blue bars in Figure 3 is a measure of the difference between the original and the amended legislation. Comparing and contrasting the green bars with the red or blue bars provides the difference between regulations for requesting conditional release and regulations for requesting conversions of remaining prison sentences into EM house arrests. Figure 3 provides a complex, detailed comparison of the three conversion schemes.

The amended legislation's conditions for switching from imprisonment to EM house arrest make this a more attractive option, or a much more attractive option (in the case of prison sentences of about 4 years), than it was under the original legislation. The only exception is for a 36-month sentence, where there is no change in relative attractiveness.

It is interesting to examine the required pre-conditions for applications for reassignment in greater detail. For the original EM monitoring scheme (red bars), the prisoners' wait to apply for a chance to apply for a switch to EM house arrest rose steadily as a proportion of their sentences, as those sentences rose, from 0.33 if the sentence was 36 months, to 0.67 if it was 72 months. Under the amended scheme (blue bars), the wait was a third of the sentence for sentences of up to 54 months, after which it rose rapidly to 0.50 for sentences of 72 months. The green bars, showing the minimum wait to submit an application for conditional release, record a simpler scheme. Prisoners had to serve half of their sentence before becoming eligible to apply for release (as explained in Section 3.1, this applied only to perpetrators of minor offences, while perpetrators of crimes had to serve two thirds of their sentence, or three quarters in the case of serious crimes).

Our view is that Figure 3 better represents the impact of the EM Law amendment on sentences of 36-72 months, than do Figure 1 or Figure 2, i.e., better than the two figures prepared and published by the MoJ. As the blue bars show, the amendment created strong incentives for prisoners to prefer conversions into EM house arrests, rather than conditional release. This was especially true for those sentenced between 48 and 60 months. For example, a prisoner with a 48-month sentence could apply for a conversion to an EM house arrest 8.2 months earlier than under the original law. The wait to file for a conditional release was, however, unchanged. 
As Figure 3 shows, the first EM Law amendment had no impact on those serving sentences of 36 months, and very little impact on those with slightly longer sentences. Soon, however, the impact kicks in and starts to become substantial. The most significant impact occurs when the sentence is 52 months. The amended regulations allow a prisoner to submit a request for a conversion of a remainder of sentence almost nine months earlier than they could submit a request for a conditional release. In an apparent inconsistency under the original legislation, prisoners serving such sentences could submit a request for the more appealing conditional release without EM two months earlier than they could submit a request for the less appealing conversion into house arrest with EM.

3.2.4. Practical Application of the "Back Door" EM Scheme 2016-2019 and Sustainability Patterns of EM in the Legal Context

Here we outline the outcomes for the first four years of the EM "back-door" scheme application. The information came from a Freedom of Information Act request to the MoJ [59], and from consultations carried out as part of the research project referred to below in the Funding section.

As shown in Figure 4, the number of successful applications for conversions of prison sentences for minor offences into EM house arrests was very low both under the original legislation in 2016-2018 (red bars) and under the amended settings in 2019 (blue bar). There was only one successful application in 2016, five in 2017, and ten in 2018 and in 2019. In stark contrast, in 2019, in the first year of the new programme, there were 78 conditional releases with mandatory EM, i.e., for first time perpetrators of crimes (in contrast with minor offenders shown in the red and blue bars).

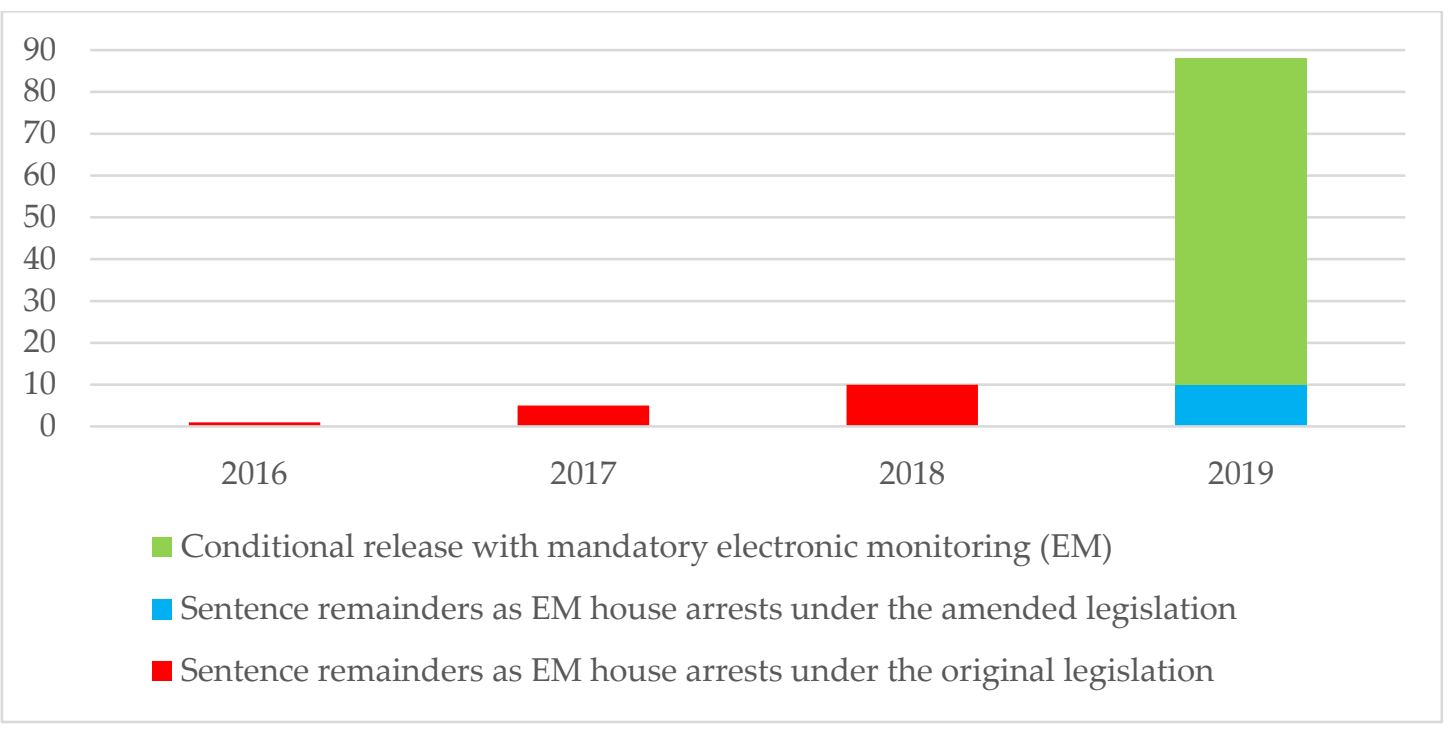

Figure 4. The annual number of sentences falling under the "back-door" scheme of electronic monitoring for (1) conversion of sentence remainders into EM house arrests (2016-2018, amended from 2019), and (2) conditional releases with mandatory electronic monitoring [58,59].

Given the above data, obtained from the MoJ [58,59], the research project noted in the Funding section was naturally focused on the very low numbers of conversions of prison sentences for minor offences into EM house arrests. According to the Yearbook of the Prison and Judicial Guards Corps, in 2016 prison directors submitted only 24 proposals for conversion, yet 670 prisoners had met the eligibility conditions [60]. Similar statistics were also reported orally for 2017 and 2018.

Although the court always decides the outcome of a proposal, under the three schemes dealt with in this paper, there are key differences in those who can propose the changes to the prisoners' conditions. Conditional releases from prison (without EM) can be proposed by prosecutors, civic associations, convicted persons or the directors of prisons in which sentences are served. In contrast, conditional releases from prisons with mandatory EM, as well as conversions of prison sentence remainders into 
electronically monitored house arrests, can only be proposed by prison directors (See Section 414a, 415 abs. 1 and 2 of Criminal procedure code.) [61].

Given Slovakia's criminal justice system's very short experience with EM, it is too soon to draw firm conclusions from our results. Some remarks are, however, in order. First, for minor offences, is the option of allowing the conversion of sentence remainders into EM house arrests sustainable (even the amendment to the original law did not lead to an increase in the use of this option)? Second, for crimes, is the option of conditional release with mandatory EM sustainable?

The very low number of conversions of prison sentence remainders into EM house arrests, shown in Figure 4, supports our opinion that the original legal conditions for this new legal instrument led to its unsustainably low use. We consider it as unsustainable mainly because the programme's small size led to high costs per person monitored.

Two years after its start, the program's low take-up led the MoJ to re-establish a working group to suggest amendments. However, as Figure 4 shows, these amendments had no impact on take-up. Most probably, although the amendments significantly increased the pool of eligible prisoners, almost all of them either did not want to apply, or their applications were rejected by prison directors. There is scope for further research here, i.e., to explore prison directors' reasons.

Our second remark concerns the introduction of the amended regulations of conditional release with mandatory EM, eligible only for first-time perpetrators of crimes, from 1 January 2019. In contrast to the very low numbers of sentence remainder conversions in 2016-2019, for persons convicted of minor offences, this new instrument was applied in 78 cases in its first year. The usage of this new instrument in 2019 was clearly much more sustainable from a cost viewpoint than the usage of an original instrument of the "back door" scheme in 2016-2018. However, we need to wait for more evidence of the new instrument's impact on recidivism, and the safety of the public, before assessing its wider sustainability in terms of all the 12 measures set out in Table 1.

Our third remark concerns international comparisons to Slovak experience. Figure 5 provides a quantitative comparison of six European "back-door" EM schemes. There were also other schemes that could be relevant comparisons, but, for example, objections to an originally ambitious Netherlands scheme led to drastic cuts in its scale [17] (so we decided not to include it into our comparison).

"Back door" EM schemes were introduced in Sweden in 2001, in Finland (2006), in Iceland (2011), in Denmark (2013), and in Norway (2014) [62]. Figure 5 includes comparable Slovak data for 2019. It shows the Slovak scheme's size was comparable to Denmark's, but small compared to those of the other Nordic countries.

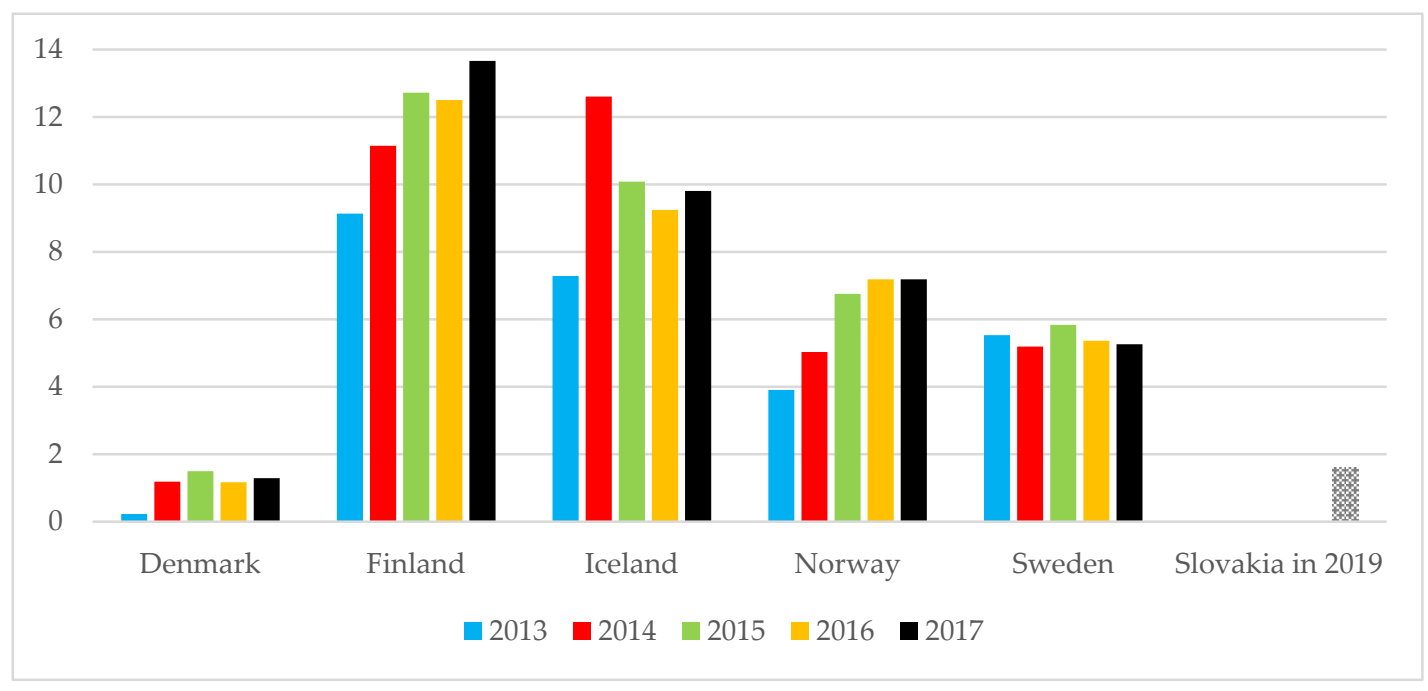

Figure 5. Use of EM "back-door" schemes, per 100,000 inhabitants, selected states. The data records new clients of the relevant probation services, arriving through such schemes in 2013-2017 [61], compared to similar Slovak data for 2019. Population data from [63]. Own calculations. 
In our view, Slovakia's initial very low EM figures may also reflect unrealistic initial expectations by the MoJ, and by the other Slovak authors of the "back-door" scheme's initial settings. This topic merits investigation in future research.

\section{Conclusions}

Exploitation of digital technologies in corrections is a big opportunity for criminal justice efficiency and sustainability. We believe that this is the first study assessing possible sustainable policy measures based on the implementation of digital technologies in corrections, namely electronic monitoring (EM) in Slovakia. Besides, the study is pioneering in presenting the legislation and practice of the Slovak EM program's "back door" scheme. It presents the results of significant desk research as well as the first Slovak national survey of views on EM, undertaken within the research project noted below in the Funding section. There are opportunities for further qualitative and quantitative research on the sustainability and improvement of digital technologies' implementation in corrections, such as electronic monitoring, in Slovakia and other countries. The results could be useful to Slovak actors and stakeholders, and others from countries that have recently set up, or are considering introducing, EM programmes. We aim to get a deeper understanding of why Slovak prison directors submitted so few proposals to convert sentences for minor offences into EM house arrests, both before and after the first EM Law amendment. This is especially important, given the large number of prisoners meeting the eligibility criteria. We suspect that many prisoners were demotivated to swap incarceration for EM house arrest. If so, we need to know why. However, it may be that prison directors did not want to risk the consequences of releases with regard to reoffending. Again, if so, we need to explore their reservations about the policy, so that any future reforms can be more effective, and hence sustainable. Or, alternatively, to reasons related to legislation concerning responsibilities and liabilities of prison directors concerning potential consequences of the reoffending (or new offences) of convicts of minor offences that could be released from prisons prematurely using this new legal instrument. These are important issues that create space for further research.

Currently, there is a debate in several countries about the exploitation of digital technologies in corrections. The discussion is related to the question of whether EM should be used as a separate form of punishment or as part of an intensive surveillance and treatment program. So the question is not whether to apply digital technologies into correction, but how. Roundly, it concerns how EM is going to be utilized in the future, whether as a standalone tool and alternative form of correction (in the context of reducing prison overcrowding and reducing public resources), or as a technical tool substituting the various non-technological instruments in national programs, probation, prison or supervision of dangerous offenders released from prison. It is worth noting that implementation of digital technologies in corrections, namely electronic monitoring, represents a widely usable tool, while its advantage is a great flexibility and the possibility of various changes related to the period of monitoring or the application of various specific requirements for monitoring [27].

$\mathrm{EM}$, based on the exploitation of digital technologies in corrections, shows the potential to achieve the difficult balance between punishments and therefore meet the public desire for a just punishment, while allowing a change in behaviour by encouraging more socially responsible behaviour of monitored persons, while ensuring their rehabilitation [64-66]. Our research results shown that EM can be perceived as a sustainable policy measure in multiple aspects, as follows: EM contributes to the reduction in the tax burden to the public, by removing the high costs associated with traditional performance penalties; EM helps to protect the offender in terms of corruption or stigmatic effects of institutional origin, but also the need to maintain family and community ties. Finally, all EM programs are aimed at suppressing crime through increased accountability and monitoring, which leads to their sustainability. This increases public safety by using more traditional approaches or community supervision, based on probation supervision and parole, and it is hoped that this approach will reduce the number of repeat offenders in the long term (for more information see $[7,14]$ ). It is important to note that implementation of digital technologies into corrections also has threats that deserve 
attention. These include the security of the system designed for monitoring, and the security of digital technologies used for monitoring and data protection. Energy supply is a necessary condition for electronic monitoring implementation. Cyber effect and security management aspects in terms of critical energy infrastructures (for more information see [67]), need to be considered as well.

Our research results are in compliance with the call for a more effective approach to use short-term EM in a manner that acts in synchrony with basic human desires-the desire to be happy, to be free of pain and to be socially valued [68]. Therefore, the person being electronically monitored does not rely only on the state, but takes the responsibility for his/her inclusion and participates personally in the costs related to execution of the sentence. Usually, the person being electronically monitored is allowed to work. We can assume that this individual will not lose working habits during the sentence and thus the transition to normal life should be relatively smooth and therefore sustainable or more resilient, without additional institutional support. An employed person being electronically monitored pays mandatory contributions to the social system. We can assume that this situation also increases consumption, which creates additional revenue for the state budget and supports its sustainability at the institutional level. Maintaining social and family ties, reducing risk of imprisonment and undesirable new ties, and keeping working habits are the main sustainable policy measures of EM at the level of individuals or communities that lead to the construction of a more inclusive society.

The assessment of the sustainable policy measures based on the implementation of digital technologies in corrections, namely electronic monitoring (EM) uncovered in the present paper, creates space for further research and policy implications. We would like to focus on in-depth research on the social aspects of the implementation of digital technologies in corrections, and their impact on recidivism and communities. Data protection related with EM, using the results of the automated data processing and possible use of artificial intelligence in the implementation of digital technologies in corrections, are important topics that deserve much more attention in research.

Author Contributions: Conceptualization, K.B., P.M., and M.O.; methodology, K.B., P.M., and M.O.; software, P.M.; validation, K.B. and M.O.; resources, K.B., P.M. and M.O.; data curation, K.B., P.M., S.K. and M.O.; writing-original draft preparation, P.M., K.B. and M.O.; writing-review and editing, P.K.; visualization, P.M.; supervision, J.K.; project administration, J.K. and K.B.; funding acquisition, K.B. All authors have read and agreed to the published version of the manuscript.

Funding: The research received funding from the Slovak Research and Development Agency (APVV) within the project "Interdisciplinary approach to electronic monitoring of accused and convicted persons in the Slovak environment", implemented under contract No. APVV 15-0437 from 2016 to 2020.

Acknowledgments: The research was supported by The Ministry of Justice (MoJ) of the Slovak republic by means of consultations carried out within the Memorandum of cooperation between the MoJ and Matej Bel University in Banská Bystrica (signed on August 2018), and also by means of data provision in accordance with the Freedom of Information Act.

Conflicts of Interest: The authors declare no conflict of interest.

\section{References}

1. Adams, M.; Klinsky, S.; Chhetri, N. Barriers to sustainability in poor marginalized communities in the united states: The criminal justice, the prison-industrial complex and foster care systems. Sustainability 2019, 12, 220. [CrossRef]

2. Clear, T.R. Imprisoning Communities: How Mass Incarceration Makes Disadvantaged Neighborhoods Worse; Oxford University Press: Oxford, UK, 2007.

3. Bazelon, E. Charged: The New Movement to Transform American Prosecution and End Mass Incarceration; Random House: New York, NY, USA, 2019; ISBN 0399590013.

4. Krištofík, P.; Borseková, K.; Koróny, S.; Mihók, P. Classical and alternative methods of punishment: Economic comparison based on European evidence. In Proceedings of the 7th International Conference on Interdisciplinary Social Science Studies, Oxford, UK, 13-15 November 2017; pp. 85-94. 
5. Nellis, M. The electronic monitoring of offenders in England and Wales. Br. J. Criminol. 1991, 31, 165-185. [CrossRef]

6. Payne, B.K.; Gainey, R.R. Electronic monitoring. J. Offender Rehab. 2000, 31, 93-111. [CrossRef]

7. Renzema, M.; Mayo-Wilson, E. Can electronic monitoring reduce crime for moderate to high-risk offenders? J. Exp. Criminol. 2005, 1, 215-237. [CrossRef]

8. Black, M.; Smith, R.G. Electronic monitoring and the criminal justice system. Trends Issues Crime Crim. Justice 2003, 254, 1-6.

9. Nellis, M. Electronic monitoring, satellite tracking, and the new punitiveness in England and Wales. In The New Punitiveness: Trends, Theories, Perspectives; Routlege: New York, NY, USA, 2013; pp. 167-188.

10. Ardley, J. The theory, development and application of electronic monitoring in Britain. Internet J. Criminol. 2005, 1-54. Available online: www.internetjournalofcriminology.com (accessed on 19 September 2020).

11. Whitfield, D. Tackling the Tag: The Electronic Monitoring of Offenders; Waterside Press: Winchester, UK, 1997.

12. Erez, E.; Ibarra, P.R.; Bales, W.D.; Gur, O.M. GPS Monitoring Technologies and Domestic Violence: An Evaluation Study; American Psychological Association: Washington, DC, USA, 2013.

13. Finn, M.A.; Muirhead-Steves, S. The effectiveness of electronic monitoring with violent male parolees. Justice Q. 2002, 19, 293-312. [CrossRef]

14. Martinovic, M. The punitiveness of electronically monitored community based programs. In Proceedings of the Probation and Community Corrections Officers' Association Inc. Conference, Perth, Australia, 23-24 September 2002.

15. Nellis, M.; Beyens, K.; Kaminski, D. Electronically Monitored Punishment: International and Critical Perspectives; Routledge: London, UK, 2013.

16. Beyens, K.; Roosen, M. Electronic monitoring in Belgium: A penological analysis of current and future orientations. Eur. J. Probat. 2013, 5, 56-70. [CrossRef]

17. Boone, M.; Pakes, F.; Van Wingerden, S. Explaining the collapse of the prison population in the Netherlands: Testing the theories. Eur. J. Criminol. 2020. [CrossRef]

18. Henneguelle, A.; Monnery, B.; Kensey, A. Better at home than in prison? The effects of electronic monitoring on recidivism in France. J. Law Econ. 2016, 59, 629-667. [CrossRef]

19. Dünkel, F.; Thiele, C.; Treig, J. “You'll never stand-alone": Electronic monitoring in Germany. Eur. J. Probat. 2017, 9, 28-45. [CrossRef]

20. Mair, G. Electronic monitoring, effectiveness, and public policy. Criminol. Public Policy 2006, 5, 57-59. [CrossRef]

21. DeMichele, M. Electronic monitoring: It is a tool, not a silver bullet. Criminol. Public Policy 2014, 13, 393-400. [CrossRef]

22. Lilly, J.R. Issues beyond empirical EM reports. Criminol. Public Policy 2006, 5, 93-101. [CrossRef]

23. Nellis, M. Surveillance, rehabilitation, and electronic monitoring: Getting the issues clear. Criminol. Public Policy 2006, 5, 103-108. [CrossRef]

24. Nellis, M. Surveillance and confinement: Explaining and understanding the experience of electronically monitored curfews. Eur. J. Probat. 2009, 1, 41-65. [CrossRef]

25. Vanhaelemeesch, D.; Beken, T.V.; Vandevelde, S. Punishment at home: Offenders' experiences with electronic monitoring. Eur. J. Criminol. 2013, 11, 273-287. [CrossRef]

26. Hucklesby, A.; Beyens, K.; Boone, M.; Dunkel, F.; McIvor, G.; Graham, H. Creativity and Effectiveness in the Use of Electronic Monitoring: A Case Study of Five Jurisdictions; European Commission; University of Leeds: Leeds, UK, 2016.

27. Hucklesby, A.; Holdsworth, E. Electronic Monitoring in England and Wales. EMEU Project Report; University of Leeds: Leeds, UK, 2016.

28. Hucklesby, A. Vehicles of desistance? Criminol. Crim. Justice 2008, 8, 51-71. [CrossRef]

29. Gibbs, A. A letter from New Zealand: Home detention-Emerging issues after the first three years. Crime Prev. Community Saf. 2004, 6, 57-64. [CrossRef]

30. Gibbs, A.; King, D. The electronic ball and chain? The operation and impact of home detention with EM in New Zealand. Aust. N. Z. J. Criminol. 2003, 36, 1-17. [CrossRef]

31. Shosham, E.; Yehosha-Stern, S.; Efodi, R. Socio-legal characteristics and parole infractions among israeli released prisoners during electronic monitoring. Int. J. Offender Ther. Comp. Criminol. 2013, 57, 864-887. [CrossRef] [PubMed] 
32. Shosham, E.; Yehosha-Stern, S.; Efodi, R. Recidivism among licenced released prisoners who participated in the EM program in Israel. Int. J. Offender Ther. Comp. Criminol. 2014, 59, 1-17.

33. Di Tella, R.; Schargrodsky, E. Criminal Recidivism after Prison and Electronic Monitoring. J. Politi- Econ. 2013, 121, 28-73. [CrossRef]

34. Slovak Legislation: Act No. 78/2015 Coll. on Control of the Enforcement of Certain Decisions by Technical Instruments. Available online: https://www.slov-lex.sk/web/en (accessed on 30 September 2020).

35. Nellis, M. Survey of Electronic Monitoring (EM) in Europe: Analysis of Questionnaires 2013 Strasbourg: Council of Europe. 2013. Available online: https://rm.coe.int/16806f9833 (accessed on 10 May 2020).

36. Aebi, M.F.; Delgrande, N. Council of Europe Annual Penal Statistics. SPACE I. Survey 2013. Available online: http://wp.unil.ch/space/files/2015/02/SPACE-I-2013-English.pdf (accessed on 20 May 2020).

37. Aebi, M.F.; Tiago, M.M.; Burkhards, C. Council of Europe Annual Penal Statistics. SPACE I. Survey 2015. 2017. Available online: http://wp.unil.ch/space/files/2017/04/SPACE_I_2015_FinalReport_161215_REV170425.pdf (accessed on 10 May 2020).

38. Laurie, E.; Maglione, G. The electronic monitoring of offenders in context: From policy to political logics. Crit. Criminol. 2019, 27, 1-18. [CrossRef]

39. Borsekova, K. Implementation of social responsibility approach into electronic monitoring: Challenge for public sector services. In Environmental Issues in Supply Chain Management; Springer Science and Business Media LLC: Berlin/Heidelberg, Germany, 2018; pp. 193-221.

40. Belur, J.; Thornton, A.; Tompson, L.; Manning, M.; Sidebottom, A.; Bowers, K. A systematic review of the effectiveness of the electronic monitoring of offenders. J. Crim. Justice 2020,68, 101686. [CrossRef]

41. Garland, D. The Culture of Control: Crime and Social Order in Contemporary Society; Oxford University Press: Oxford, UK, 2002.

42. Vitálišová, K.; Borseková, K.; Vaňová, A. Benefits and risks associated with the electronic monitoring of accused and convicted persons implementation from the community life point of view. In Proceedings of the 7th Central European Conference in Regional Science, Sopron, Hungary, 9-11 October 2019.

43. National Audit Office. The EM of Offenders. 2006. Available online: https://www.nao.org.uk/report/theelectronic-monitoring-of-adult-offenders/ (accessed on 26 March 2020).

44. Dodgson, K.; Goodwin, P.; Howard, P.; Clewellyn-Thomas, S.; Mortimer, E.; Russell, N.; Weiner, M. EM of Released Prisoners: An Evaluation of the Home Detention Curfew Scheme, Home Office Research Study 222; Home Office: London, UK, 2001.

45. Mair, G.; Mortimer, E. Curfew Orders with Electronic Monitoring; Home Office Research and Statistics Directorate: London, UK, 1996.

46. Mair, G.; Nee, C. Electronic Monitoring. The Trials and Their Results, Home Office Research Study No. 120; The Stationary Office: London, UK, 1990.

47. Shute, S. Satellite Tracking of Offenders. A Study of the Pilots in England and Wales, Research Summary 4; Ministry of Justice: London, UK, 2007.

48. Sugg, D.; Moore, L.; Howard, P. Electronic Monitoring and Offending Behaviour-Reconviction Results for the Second Year of Trials of Curfew Orders; Home Office Research Findings 141: London, UK, 2001.

49. Borseková, K.; Krištofík, P.; Koróny, S.; Mihók, P.; Vaňová, A. Electronic monitoring as an alternative form of punishment: An exploratory study based on European evidence. In Proceedings of the 7th International Conference on Interdisciplinary Social Science Studies, Oxford, UK, 13-15 November 2017; pp. 95-107.

50. Aebi, M.F.; Tiago, M.M. SPACE I-Council of Europe Annual Penal Statistics: Prison Populations; Council of Europe: Strasbourg, France, 2018.

51. Vitálišová, K.; Mihók, P.; Vaňová, A. Electronic monitoring of convicted and accused persons as a more cost-efficient way of punishment. In Proceedings of the Právne a Ekonomické Súvislosti Elektronického Monitoringu Obvinených a Odsúdených Osôb, Banská Bystrica, Slovakia, 21-22 November 2019; pp. 414-424.

52. Cohen, M.A.; Piquero, A.R. New evidence on the monetary value of saving a high risk youth. J. Quant. Criminol. 2009, 25, 25-49. [CrossRef]

53. Marklund, F.; Holmberg, S. Effects of early release from prison using electronic tagging in Sweden. J. Exp. Criminol. 2009, 5, 41-61. [CrossRef]

54. Nellis, M. Surveillance, stigma and spatial constraint: The ethical challenges of electronic monitoring. In Electronically Monitored Punishment: International and Critical Perspectives; Nellis, M., Beyens, K., Kaminski, D., Eds.; Routledge: Oxford, UK, 2013; pp. 193-210. 
55. Padgett, K.G.; Bales, W.D.; Blomberg, T.G. Under surveillance: An empirical test of the effectiveness and consequences of electronic monitoring. Criminol. Public Policy 2006, 5, 61-91. [CrossRef]

56. Payne, B.K.; DeMichele, M. Sex offender policies: Considering unanticipated consequences of GPS sex offender monitoring. Aggress. Violent Behav. 2011, 16, 177-187. [CrossRef]

57. Slovak Legislation: Act No. 321/2018 Coll., Amending Act no. 550/2003 Coll. on Probation and Mediation Officers and Amending and Supplementing Certain Other Acts. Available online: https://www.lexadin.nl/ wlg/legis/nofr/eur/lxweslw.htm (accessed on 30 September 2020).

58. Ministry of Justice of the Slovak Republic. Návrh zákona, ktorým sa mení a dopĺña zákon č. 550/2003 Z. z. o probačných a mediačných úradníkoch a o zmene a doplnení niektorých zákonov v znení neskorších predpisov a ktorým sa menia a dopĺńajú niektoré zákony. Document no. 36766/2018/120 dated August 2018, approved by the Resolution of the Government of the Slovak Republic no. 365 on 22 August 2018. Bratislava: MoJ. 2018. Available online: https://rokovania.gov.sk/RPO/Material/1729/1 (accessed on 26 February 2018).

59. Ministry of Justice of the Slovak Republic. Answer on the Request for Information (submitted under the Freedom of Information Act) Number sp. zn.: 27/2020-142-I. Bratislava: MoJ, 2020 (obtained by email on 29 January 2020). Available online: https://issat.dcaf.ch/Share/People-Organisations/Organisations/Ministryof-Justice-Slovakia (accessed on 30 September 2020).

60. Prison and Court Guard Service [of the Slovak Republic]. Yearbook of the Prison and Court Guard Service-2016. Page 11. Bratislava: Prison and Court Guard Service. 2017. Available online: http: //www.justice.gov.sk/stat/roc/17/Činnost'\%20ZVJS.pdf (accessed on 16 March 2020).

61. Slovak Legislation: Act No. 301/2005 Coll. Criminal Procedure Code as Amended. Available online: https://www.google.com.hk/url?sa=t\&rct=j\&q=\&esrc=s\&source=web\&cd=\&ved=2ahUKEwimv9Wh1b_ sAhUOrZQKHegfChAQFjAAegQIAxAC\&url=https\%3A\%2F\%2Ftbinternet.ohchr.org\%2FTreaties \% 2FCED\%2FShared\%2520Documents\%2FSVK\%2FINT_CED_ADR_SVK_31018_E.doc\&usg= AOvVaw2XQmnmbzkox_DEOivx2Zp- (accessed on 30 September 2020).

62. Kristoffersen, R. Correctional Statistics of Denmark, Finland, Iceland, Norway and Sweden 2013 -2017. University College of Norwegian Correctional Service: Lillestrøm. 2019. Available online: https://krus.brage. unit.no/krus-xmlui/handle/11250/2590195 (accessed on 28 February 2018).

63. Chen, M.-Y.; Wu, F.-C.; Meng, L.-M.; Cheng, S.-M.; Chao, C.-H.; Pu, C.-E. Population data on X chromosome short tandem repeat loci HPRTB and AR in Taiwan. Forensic Sci. Int. 2002, 126, 171-172. [CrossRef]

64. Gainey, R.R.; Payne, B.K. Understanding the experience of house arrest with electronic monitoring: An analysis of quantitative and qualitative data. Int. J. Offender Ther. Comp. Criminol. 2000, 44, 84-96. [CrossRef]

65. Gainey, R.R.; Payne, B.K.; O'Toole, M. The relationships between time in jail, time on electronic monitoring, and recidivism: An event history analysis of a jail-based program. Justice Q. 2000, 17, 733-752. [CrossRef]

66. White, P.; Cullen, C.; Minchin, M. Prison Population Brief England and Wales: September 1999, Offenders and Corrections Unit, Research, Development and Statistics Directorate, 2000; Home Office: London, UK, 2000.

67. Plèta, T.; Tvaronavičienè, M.; Della Casa, S. Cyber effect and security management aspects in critical energy infrastructures. Insights Reg. Dev. 2020, 2, 538-548. [CrossRef]

68. Kilgore, J. Progress or more of the same? Electronic monitoring and parole in the age of mass incarceration. Crit. Criminol. 2012, 21, 123-139. [CrossRef]

Publisher's Note: MDPI stays neutral with regard to jurisdictional claims in published maps and institutional affiliations.

(C) 2020 by the authors. Licensee MDPI, Basel, Switzerland. This article is an open access article distributed under the terms and conditions of the Creative Commons Attribution (CC BY) license (http://creativecommons.org/licenses/by/4.0/). 